\title{
ROLE OF IMMATURE/TOTAL NEUTROPHIL RATIO, LEUKOCYTE COUNT AND PROCALCITONIN IN DIAGNOSING NEONATAL SEPSIS
}

\author{
I A Putri Wirawati ${ }^{1}$, Aryati $^{2}$, A A Wiradewi Lestari ${ }^{1}$ \\ ${ }^{1}$ Department of Clinical Pathology, Faculty of Medicine, Udayana University/Sanglah Hospital, Denpasar, Indonesia. E-mail: \\ ia.wirawai@gmail.com ${ }^{2}$ Department of Clinical Pathology, Faculty of Medicine, Airlangga University/Dr Soetomo Hospital, \\ Surabaya, Indonesia
}

\begin{abstract}
Neonatal sepsis is a clinical syndrome of systemic disease, accompanied by bacteremia that occurs during infants in the first month of life. A late diagnosis might increase mortality. The presence of bacteria growth in blood cultures is a definitive diagnosis. Unfortunately, culture results are usually obtained of a long time. The study aimed to analyze sensitivity and specificity of the manual $I / T$ ratio, automatic $I / T$ ratio, leukocyte count and procalcitonin (PCT) to diagnose neonatal sepsis. This study used a cross-sectional design, from the NICU room in Sanglah General Hospital, Denpasar. There were 59 patients who met the study criteria. Along with blood culture as the gold standard in determining diagnosis of sepsis and with $\mathrm{I} / \mathrm{T}$ ratio cutoff of 0.2 , the sensitivity of manual I/T ratio was $69.2 \%$, specificity $83.9 \%$, PPV $63.9 \%$, NPV $87 \%$ and likelihood ratio was 3.06 . While the sensitivity of automatic I/T ratio was $47.6 \%$, specificity $85.8 \%$, PPV $55.1 \%$, NPV $81.4 \%$ and likelihood ratio was 2.25 . Based on the normal range of leukocyte count $\left(9.1-34 \times 10^{3 /} \mu \mathrm{l}\right)$, sensitivity of leukocyte count was $59 \%$, specificity $71.5 \%$, PPV $46.7 \%$, NPV $80.9 \%$ and likelihood ratio was 1.59 . With PCT cut -off $0.5 \mathrm{ng} / \mathrm{mL}$, the obtained sensitivity of PCT was $64.3 \%$, specificity $85.8 \%$, PPV $64.3 \%$, NPV $85.8 \%$ and likelihood ratio was 3.13 .
\end{abstract}

Key words: Neonatal sepsis, I/T ratio, leucocyte, procalcitonin, blood culture

\section{INTRODUCTION}

Infectious diseases still become a major health problem in developing countries, including Indonesia. Newborn infections and low birth weight are still very common in Indonesia, some of which will develop into septicemia. Systemic infection in newborns is a common cause of death in neonates. ${ }^{1}$ The National Neonatal Perinatal Database 2,000 showed that the incidence of neonatal sepsis was 38 per 1,000 live births, in the tertiary health center. ${ }^{2}$ The incidence of neonatal sepsis in Indonesia at some referral hospitals is still very high, between $8.76 \%-30.29 \%$ with mortality rate $11.56 \%$ $-49.9 \%$.

In addition, the incidence of septicemia of the newborn in Indonesia is between $1.5 \%-3.72 \%$ with a mortality rate of $37.0 \%-80 \%$. Early neonatal infection can be caused by vertical transmision from the mother. Its mortality rate was $5-20 \%$. In developing countries such as India it was found that Klebsiella pneumoniae was the most common causal organism, followed by Staphylococcus aureus and Pseudomonas. Causal organism varies in some hospitals. At the Cipto Mangunkusumo Hospital, Salmonella typhi, Escherichia coli and Pseudomonas are the most common organisms. Infection could occur antenatal, intranatal and postpartum. Diagnosis and early detection should be done as soon as possible to give the best prognosis. ${ }^{3}$ Blood culture remains a gold standard, but its results are obtained after 48-72 hours and the results might be influenced by antibiotics given at the time of delivery, only 30$40 \%$ will give a positive result. ${ }^{4.5}$

Response to infection is characterized by several signs of sepsis including hyperthermia (temperature $>38^{\circ} \mathrm{C}$ ) or hypothermia (temperature $<36^{\circ} \mathrm{C}$ ), tachycardia (heart rate $>160 \times /$ minute), tachypnea (respiratory rate $>60 \mathrm{x} / \mathrm{min}$ ). It will lead to 
septicemia, organ dysfunction, hypoperfusion, hypoxemia and lactoacidosis. This early stage condition often could not be identified/diagnosed, so laboratory diagnostics are needed. Considering a high mortality of sepsis, adequate treatment should not be delayed. ${ }^{6}$

Several other parameters can be used to diagnose neonatal sepsis including: shift to the left, hematology scoring system, manual $I / T$ ratio, automatic $1 / T$ ratio and procalcitonin..$^{7-9}$ Neutrophils are first line cells which are responsible to human body's immune system. Neutrophils are not much found in the beginning of a baby's life. Neutrophils count varies in the first weeks of birth and the lowest level is found at the time of delivery $(1,800$ per milimeter cubic then increased to 7,200 per milimeter cubic at 12 hours after birth). Infection will cause more neutrophils found in the blood. Neutrophils count is relatively low at birth compared to adults. Shift to the left is usually used for early diagnosis of bacterial infections. Shift to the left is an increase of immature leukocytes in peripheral blood, mainly band neutrophils. Neonatal infections will increase neutrophil counts in accordance to the severity of infection. ${ }^{9-11}$

Shift to the left describes the bone marrow response to bacterial infection. Counting the bands manually has been used in the pediatric department to diagnose bacterial infection, but it is very difficult to determine its accuracy. Therefore, measurement of granulocytes to predict sepsis or infection now can be done using an automatic Cell-dyne Ruby hematology analyzer. ${ }^{12}$

Several methods to count the number of leucocyte need to be done for early diagnosis of neonatal sepsis, such as by counting immature neutrophils (band, metamyelocyte, myelocyte, promyelocyte) against total neutrophils ( $\mathrm{I} / \mathrm{T}$ ratio) as an early marker of neonatal sepsis. $I / T$ ratio is the ratio between immature and total number of neutrophils. $1 / T$ ratio can be calculated manually (using a microscope) and automatically (using a reading device). The young granulocytes are usually found in the presence of infection and septicemia. In the WBC differential count, shift to the left can be seen and $\mathrm{I} / \mathrm{T}$ ratio will increase as an early marker of septicemia in newborns, in which $\mathrm{I} / \mathrm{T}$ ratio $>0.2$ accompanied by leukopenia. $\mathrm{I} / \mathrm{T}$ ratio in non-infected neonates is 0.16 in the first 24 hours of birth and will decline to 0.12 within 60 hours after birth. ${ }^{13}$

Procalcitonin (PCT) can be used as an early marker of sepsis caused by bacteria and is the prohormone of calcitonin-forming protein consisting of 116 amino acids. The half-life time of PCT is $25-30$ hours. The location of PCT synthesis is unknown, but it was suggested that PCT is formed by monocytes and liver cells. Procalcitonin concentration increases within 3-4 hours after exposure to endotoxin and reaches the highest level in six hours and will remain high for more than 24 hours. PCT has been studied intensively as a neonatal sepsis diagnosis marker. Several studies reported that higher plasma concentrations of PCT were found in infants with severe infection and a low titer of PCT was found when there was no signs of infection. The sensitivity of PCT in the early neonatal sepsis was $83 \%-100 \%$, while the specificity was $70 \%-100 \% .^{14-16}$

Due to the variety of clinical symptoms and difficulty to diagnose sepsis early in neonates, it is necessary to investigate the role of $1 / T$ ratio, leukocytes count and PCT to diagnose neonatal sepsis.

\section{METHODS}

This cross-sectional study was conducted in October 2015 through December 2015. Study samples were newborns up to 28 days of age who had risk factors for neonatal sepsis and/or had clinical symptoms of sepsis and were admitted to the NICU ward in Sanglah Hospital. Laboratory tests were conducted at the Laboratory of Clinical Pathology Sanglah Hospital, Denpasar. A total of 59 samples were taken consecutively using inclusion criteria that had at least one major risk factor for neonatal sepsis, two minor risk factors for neonatal sepsis, one or more clinical symptoms of sepsis (clinically sepsis) and obtained informed consent from their parents.

Major risk factors for neonatal sepsis inculded membrane rupture> 24 hours, maternal temperatures $>38^{\circ} \mathrm{C}$ intrapartum, chorioamnionitis, fetal heart rate $>160$ beats/min and bad smelling amniotic fluid. Minor risk factors for neonatal sepsis included membrane rupture 12-24 hours, maternal temperature of 37.5 to $38^{\circ} \mathrm{C}$ intrapartum, low Apgar score, very low birth weight $(<1,500 \mathrm{~g})$, gestational age $<37$ weeks, multiple pregnancy, untreated discharge and suspected maternal urinary tract infection. Clinical symptoms of sepsis included lethargy, bad sucking reflex, fever, low or high pitch cry, seizures, cardiovascular disorders (pallor, cyanosis, cold), respiratory distress (tachypneu, 
apnea, moaning, retractions), gastrointestinal disorders (vomiting, diarrhea, abdominal distension), hematological system disorders (bleeding, icterus), purpura and pustules.

Table 1. Characteristics of the research samples

\begin{tabular}{|c|c|c|}
\hline & Number & Percentage (\%) \\
\hline \multicolumn{3}{|l|}{ Sex : } \\
\hline Male & 36 & 61.01 \\
\hline Female & 23 & 38.99 \\
\hline \multicolumn{3}{|c|}{ Neonates age (days) } \\
\hline $0-3$ & 20 & 33.89 \\
\hline$>3$ & 39 & 66.11 \\
\hline \multicolumn{3}{|l|}{ LBW (gram) } \\
\hline$<2500$ & 36 & 61.01 \\
\hline$>2500$ & 23 & 38.99 \\
\hline \multicolumn{3}{|c|}{ Maternal temperature } \\
\hline$>38^{\circ} \mathrm{C}$ & 4 & 6.79 \\
\hline$\geq 37.5^{\circ} \mathrm{C}$ & 1 & 1.69 \\
\hline No fever & 54 & 91.52 \\
\hline \multicolumn{3}{|l|}{ Gestational age } \\
\hline Preterm & 35 & 59.32 \\
\hline Aterm & 24 & 40.68 \\
\hline \multicolumn{3}{|c|}{$\begin{array}{l}\text { Premature Rupture of } \\
\text { Membrane (PROM) }\end{array}$} \\
\hline$>12$ hours & 2 & 3.39 \\
\hline$>24$ hours & 4 & 6.78 \\
\hline Without PROM & 53 & 89.83 \\
\hline \multicolumn{3}{|l|}{ Mode of delivery } \\
\hline Vaginal delivery & 39 & 66.11 \\
\hline Caesarian section & 19 & 32.20 \\
\hline Forceps & 1 & 1.69 \\
\hline \multicolumn{3}{|l|}{ WBC count } \\
\hline$<9 \times 10^{3} / \mu \mathrm{L}$ & 21 & 35.59 \\
\hline $9.1-34 \times 10^{3} / \mu \mathrm{L}$ & 37 & 62.72 \\
\hline$>34 \times 10^{3} / \mu \mathrm{L}$ & 1 & 1.69 \\
\hline
\end{tabular}

Calculation of $\mathrm{I} / \mathrm{T}$ ratio was obtained through dividing the number of immature neutrophils by the total number of neutrophils. The results of the immature neutrophil ratio compared to total neutrophils $>0.20$ indicated a bacterial infection. In addition to manually reading/microscopically, the results of $1 / T$ ratio was also obtained through comparing immature granulocytes with total neutrophil band using Cell-Dyne Ruby instrument. Leukocyte count obtained from Cell-Dyne Ruby and PCT levels measured by Cobas E411. Normal range of leukocyte counts were $9 \times 10^{3} / \mu \mathrm{L}-34 \times 10^{3} / \mu \mathrm{L}$. Levels of PCT $<0.5 \mathrm{ng} / \mathrm{mL}$ showed a low risk, while 0.5 to $2.00 \mathrm{ng} / \mathrm{mL}$ showed a moderate risk and >
$2.00 \mathrm{ng} / \mathrm{mL}$ showed a high risk of sepsis.

\section{RESULT AND DISCUSSION}

A total number of 59 suspected neonatal sepsis was infants included as research subjects. Data obtained were statistically analyzed to look for sensitivity, specificity, Positive Predictive Value (PPV), Negative Predictive Value (NPV) and likelihood Ratio (LR).

Table 2. Sensitivity, specificity, LR, PPV and NPV

\begin{tabular}{lccccc}
\hline Parameter & $\begin{array}{c}\text { Sensitivity } \\
\text { (\%) }\end{array}$ & $\begin{array}{c}\text { Specificity } \\
\text { (\%) }\end{array}$ & $\begin{array}{c}\text { LR } \\
\text { PPV } \\
\text { (\%) }\end{array}$ & $\begin{array}{c}\text { NPV } \\
\text { (\%) }\end{array}$ \\
\hline $\begin{array}{l}\text { Manual I/T } \\
\text { ratio }\end{array}$ & 69.2 & 83.9 & 3.06 & 63.9 & 87 \\
$\begin{array}{l}\text { Automatic } \\
\text { I/T ratio }\end{array}$ & 47.6 & 85.8 & 2.25 & 55.1 & 81.4 \\
$\begin{array}{l}\text { Leukocyte } \\
\text { count }\end{array}$ & 59 & 71.5 & 1.59 & 46.7 & 80.9 \\
$\begin{array}{l}\text { Procalciton- } \\
\text { in }\end{array}$ & 64.3 & 85.8 & 3.13 & 64.3 & 85.8 \\
\hline
\end{tabular}

Using the blood cultures as a gold standard of sepsis diagnosis, the sensitivity of manual I/T ratio was $69.2 \%$, specificity $83.9 \%$ and LR of 3.06 . Sensitivity of automatic I/T ratio was $47.6 \%$, specificity $85.8 \%$ and LR 2.25. Leukocyte count had a $59 \%$ sensitivity, $71.5 \%$ specificity and LR 1.59. PCT sensitivity was 64.3\%, specificity $85.8 \%$ and LR of 3.13 .

Procalcitonin (PCT), a serological marker in the form of a prohormone has been widely studied to have a determinant role in the etiology of infectious diseases. ${ }^{17}$ Procalcitonin levels in some previous studies had various sensitivity, specificity and the cut-off points. ${ }^{16,17} \mathrm{~A}$ research by Sucilathangan in India, showed a sensitivity and specificity of PCT amounting to $92.8 \%$ and $75.0 \%$ in neonates, with PPV $59 \%$ and NPV $96 \% .{ }^{18}$ Stephani, in Texas USA, used a cut-off point of $0.6 \mathrm{ng} / \mathrm{mL}$ and found that the sensitivity and specificity of PCT was $100 \%$ and $65 \%$ with $67 \%$ PPV and NPV of $100 \% .{ }^{16}$

Sakha, in Pakistan used a cut-off $2 \mathrm{ng} / \mathrm{mL}$ scored PCT sensitivity and specificity of $66.7 \%$ and $50 \%$, PPV and NPV 28.6\% 83.3\%. ${ }^{19}$ Jose in Spain used a cutoff point of $0.55 \mathrm{ng} / \mathrm{mL}$, thus got the sensitivity and specificity of PCT as $75.4 \%$ and $72.3 \%{ }^{20}$ Khosdell, in Iran, used a cut-off point of $2 \mathrm{ng} / \mathrm{mL}$, found that the sensitivity and specificity were $87.5 \%$ PCT and $87.4 \%{ }^{20}$ With the same cut-off, Suryanto, in the Dr. Kariadi Hos- 
pital scored PCT sensitivity and specificity of $66.6 \%$ and $44.4 \%$, with PPV $37 \%$ and NPV $72.7 \%{ }^{21}$

In this study, the sensitivity and specificity of PCT were $64.3 \%$ and $85.8 \%$ with $64.3 \%$ PPV and NPV of $85.8 \%$. That finding was caused by the use of different cut-off and also the time of blood sampling for examination of PCT levels that was different from other studies.

Table 3. Sensitivity, specificity and cut-off of PCT

\begin{tabular}{lccc}
\hline \multicolumn{1}{c}{ Research } & $\begin{array}{c}\text { Sensitivity } \\
\text { (\%) }\end{array}$ & $\begin{array}{c}\text { Specificity } \\
(\%)\end{array}$ & $\begin{array}{c}\text { Cut-off } \\
\text { (ng/mL) }\end{array}$ \\
\hline Jose, 2007 & 75.4 & 72.3 & 0.55 \\
Khosdell, 2008 & 87.5 & 87.4 & 2 \\
Sakha, 2008 & 66.7 & 50 & 2 \\
Suryanto, 2012 & 66.6 & 44.4 & 2 \\
Sucilathangan, & 92.8 & 75.0 & 0.5 \\
2013 & & & \\
Stephani, 2014 & 100 & 65 & 0.6 \\
Wirawati, 2016 & 64.3 & 85.8 & 0.5 \\
\hline
\end{tabular}

A research by Ang, in Singapore, found that the sensitivity and specificity of $1 / T$ ratio were $47 \%$ and $91 \%$ with PPV $76 \%$ and NPV $66 \% .{ }^{13}$ In the study by Kelly, the sensitivity and specificity of $1 / T$ user ratio were $33 \%$ and $88 \%$, PPV $64 \%$, NPV $68 \% \%$ with the cut off point $>0.2 .^{22}$ With the same cut-off, Darni Fayanti, in Medan, obtained a sensitivity and specificity of $\mathrm{I} / \mathrm{T}$ ratio as $88.46 \%$ and $81.84 \%$ to 82.14\% PPV and NPV 88\%, LR 4.776.

Darni mentioned that $\mathrm{I} / \mathrm{T}$ ratio could be used as an alternative to blood cultures to determine early bacterial infection such as sepsis in neonates, because the results could be obtained quickly, inexpensive and has good sensitivity and specificity. Also with the same cut-off, in 1980 in the United States, it is obtained a sensitivity of $\mathrm{I} / \mathrm{T}$ ratio of $90 \%$ and a specificity of $78 \%$, while in Australia, the sensitivity of $\mathrm{I} / \mathrm{T}$ ratio was $96 \%$ and specificity $71 \%$ and in the Netherlands (1999), obtained a sensitivity of $89 \%$ and a specificity of $82 \%$. By using a cut-off of $\mathrm{I} / \mathrm{T}$ ratio $>0.15$ in California, was obtained a sensitivity of $89 \%$ and a specificity of $94 \%{ }^{23}$

$\mathrm{I} / \mathrm{T}$ ratio could be used as a dignose instrument for early diagnosis of bacterial sepsis in neonates because $1 / T$ ratio had a high sensitivity and specificity. In this study, out of 59 samples, showed a sensitivity and specificity of $1 / T$ ratio manually by $69.2 \%$, and $83.9 \%, 63.9 \%$ PPV, NPV $87 \%$
69.2\% , and $83.9 \%, 63.9 \%$ PPV, NPV $87 \%$ and LR of 3.06 . As for $1 / T$ ratio with values obtained using an automated instrument showed sensitivity and specificity of $47.6 \%$ and $85.8 \%, 55.1 \%$ PPV, NPV $81.4 \%$ and LR 2.25. The difference with the results of other studies may be caused by differences in sampling time, as it is known that the $1 / T$ ratio peaked in the first 12 hours of a baby's life.

Xanthou, mentioned that the leukocytes were routinely used to determine sepsis due to bacterial infections in infants, children or adults, even the number of leukocytes, differential cell count and I/T ratio were also used as a filter of neonatal sepsis. However, none of these examinations could be used in the determination of the main causes of neonatal sepsis. Wintrobe, found that during infancy, leukocyte count varied greatly until the age of 26 weeks of life. ${ }^{24}$ In this study, the sensitivity and specificity of the leukocyte count were $59 \%$ and $71.5 \%$ with $46.7 \%$ PPV and NPV $80.9 \%$, respectively.

Simonsen, obtained an unfavorable value of PPV to the number of leukocytes in neonates with sepsis, but neutropenia had a very high specificity for neonatal sepsis. Neutropenia is highly dependent on gestational age, mode of delivery and height. ${ }^{4}$ Hornick, in his study by using the Complete Blood Count (CBC) in early-onset sepsis, found that a low white cell count and absolute neutrophil count and high $\mathrm{I} / \mathrm{T}$ ratio related to odds ratio of infection. The odd ratio for white cell count amounted to $5.28 \%, 6.84 \%$ for absolute neutrophil and $7.97 \%$ for $1 / T$ ratio. The leukocyte count had a high value of specificity and NPV $(73.7 \%-99.9 \%)$, but the sensitivity was low $(0.3 \%$ $54.55 \%)^{25}$

Table 4. Sensitivity, specificity and cut off of $1 / T$ ratio researches

\begin{tabular}{lccc}
\hline \multicolumn{1}{c}{ Researches } & $\begin{array}{c}\text { Sensitivity } \\
\text { (\%) }\end{array}$ & $\begin{array}{c}\text { Specificity } \\
\text { (\%) }\end{array}$ & Cut-off \\
\hline USA, 1980 & 90 & 78 & $>0.2$ \\
Ang, 1990 & 47 & 91 & $>0.2$ \\
The Netherlands, 1999 & 89 & 82 & $>0.2$ \\
Kelly, 2005 & 33 & 88 & $>0.2$ \\
Darni Fayanti, 2015 & 88.46 & 81.84 & $>0.2$ \\
California & 89 & 94 & $>0.15$ \\
Wirawati, 2016: & & & \\
- manual & 69.2 & 83.9 & $>0.2$ \\
- automatic & 47.6 & 85.8 & $>0.2$ \\
\hline
\end{tabular}


Blood cultures is an examination method for detecting the presence of pathogenic bacteria in the blood. The pattern of the bacteria that cause neonatal sepsis varies greatly across regions and over time. In some developing countries, neonatal sepsis-causing bacteria are Gram negative enteric bacteria, such as Enterobacter Spp, Klebsiella Spp and Escherichia coli. In this study, the microorganisms that caused sepsis was Gramnegative bacteria as much as $33.9 \%$, with these types of microorganisms as much as $6.5 \%$ of Klebsiella pneumoniae, Acinetobacter baumannii 6.5\%, Enterobacter cloacae $4.8 \%$ negative coagulase Staphylococcus 3.2\%, Staphylococcus aureus 1.6\%, Staphylococcus epidermidis $1.6 \%$, Staphylococcus haemolyticus 1.6\%, Serratia marcescens $1.6 \%$ and Pseudomonas stutzeri 1.6\% were found.

In addition to bacterial infections, fungal infections were also found with the type of fungus Candida parapsilosisas $1.6 \%$ and $3.2 \%$ Kodamea ohmeri. From these data, high incidence of sepsis due to Gram-negative bacteria, considered as sepsis caused by microorganisms that were usually acquired in hospitals.

Based on data from the Microbiology Department of Sanglah Hospital, it was found that the most often bacteria causing sepsis in the NICU in January to July 2015 was a Gram negative bacterium such as Acinetobacter baumannii, coagulase-negative Staphylococcus, Pseudomonas aeruginosa, Enterobacter cloacae, Klebsiella pneumoniae, Staphylococcus epidermidis, which corresponded to the results of this research that was Acinetobacter baumannii, negative coagulase Staphylococcus, Klebsiella pneumoniae, Enterobacter cloacae, Klebsiella pneumoniae, Staphylococcus epidermidis and Staphylococcus haemolyticus. ${ }^{26}$

The weakness of this study was the limited sample since the examination of PCT as a method for detecting sepsis is still yet to be standardized for diagnosis and treatment in Sanglah Hospital as a sampling study. Cross-sectional design also caused the researcher did not follow the development of patients clinically. The period in taking blood samples for PCT and $\mathrm{I} / \mathrm{T}$ ratio examination also varied.

\section{CONCLUSION AND SUGGESTION}

As a diagnostic marker of neonatal sepsis, PCT
PCT had a sensitivity of $64.3 \%$ and a specificity of $85.8 \%$; the number of leukocytes had a sensitivity of $59 \%$ and a specificity of $71.5 \%$; manual $\mathrm{I} / \mathrm{T}$ ratio had a sensitivity of $69.2 \%$ and a specificity of $83.9 \%$; automatic $\mathrm{I} / \mathrm{T}$ ratio tool had a sensitivity of $47.6 \%$ and a specificity of $85.8 \%$. Further research is needed with larger sample sizes to prove the broader role of PCT and $\mathrm{I} / \mathrm{T}$ ratio in the diagnosis of neonatal sepsis.

Researchers purposed larger sample sizes and completed methods of the research to increased implementation of the level PCT and $I / T$ ratio in diagnosed of neonatal sepsis

\section{REFERENCES}

1. Herry Garna. Pedoman Diagnosis dan terapi IKA, Ed 3., Bandung, Bagian IKA FK Unpad, 2005; 109-112.

2. Arijit Majumdar, Angshuman Jana, Soumali Biswas, Swagata Bhattacharyya. Hematological scoring system (HSS); A Guide to decide Judious use of antibiotic in neonatal septicemia in developing countries. 2013; 4(3): 110 $-113$.

3. Sepsis neonatorum. Standar pelayanan medik divisi Perinatologi FKUI /RSCM 2004; 21-33.

4. Kari A. Simonsen, Ann L. Anderson-Berry F. Delair H. Dele Davies. Early-Onset Neonatal Sepsis. Clin. Microbiol. Rev. 2014; 27(1): 1 21-47.

5. Sagori Mukhopadhyay and Karen M. Puopolo. Risk assessment in neonatal early-onset sepsis. SeminPerinatol, 2012; 36(6): 408-415.

6. Goldstein B, Giror B, Randolph A. International consensus conference on pediatric sepsis. Pediatr Crit Care Med. 2005; 6(1): 2-8.

7. Polin RA. Management of neonates with suspected or proven early onset bacterial sepsis. Pediatr. 2012; 129 (5): 1006-15.

8. Wacker C, Prkno A, Brunkhorst FM, Schlattmann P. Procalcitonin as a diagnostic marker for sepsis: A systemic review and meta-analysis. Lancet Infect. Dis. 2013; 13 (5): 426-35.

9. Mohamed ISI, Wynn RJ, Cominsky K, Reynolds AM, Ryan RM, Kumar VH, Akshminrusimha SL. White blood cell left shift in a neonate: A case of mistaken identity. Journal of Perinatology. 2006; 26(6): 378-80.

10. Balamurugan S, Treshul K, Jayapriya S, Jeya M, Ramesh Rao K. Automated measurement of immature granulocytes: performance characteristics and utility in routine clinical practice. Pathology Research International. (2012): http://dx.doi.org/10.1155/2012/483670.

11. Christensen RD, Bradley PP, Rothstein G. The leukocyte left shift in clinical experimental neonatal sepsis (Abstract). J. Pediatr. 1981; 98(1): 101-5.

12. Lehto T, Hedberg P. Performance evaluation of Abbott, 
CELL-DYN Ruby for routine use. Int J Lab Hematol, 2008; 30(5): 400-7.

13. A Ng-AT, Hon Chia Se. The Usefullness of CRP and I/T Ratio in Early Diagnosis of Infections. The Journal of the Singapore Pediatric Society. 1990, 32(3-4): 159163.

14. Ekrem Guler, Mehmet Davutoglu, Hasan Ucmak, Hamza Karabiber and faruk Kokoglu. An outbreak of serratia marcescens septicemia in neonates. Indian Pediatric Journal, 2009; 46(17): 61-69.

15. Michael Meisner. Procalcitonin - Biochemistry and Clinical Diagnosis I ${ }^{\text {st }}$ Eds., Bremen, Uni-Med, 2010; 111.

16. Stephani I, Ramires. Procalcitonin in neonatal sepsis, May, 2014, Site U texas.edu.file Ramirez 05.09.14. 2013; 3: 22-8.

17. Eviridiki K. Vouloumanov, Eleni Plessa Drosos E, Kara Georgo Povles, Elpis Manta Dakis, Mattew E. Falagas. Serum procalcitonin as a diagnostic marker for neonatal sepsis: A systematic review and metaanalysis. Intensive Care Med, 201; 37: 747-762.

18. Susilathangan $G$, Amothavali K, Velvichi G, Ashihabegom MA, JeyaMurugan T, Palaniappan N. Early diagnostic markers for neonatal sepsis; Comparing Procalcitonin (PCT) and C-Reactive Protein (CRP). 2012; 6(4): 627-631.

19. Sakha K, Husseni MB, Seyyedesadri N. The Role of procalcitonin in the diagnosis neonatal sepsis and correlation between procalcitonin and C-reactive protein. Pakistan J, Biological Scien, 2008; 11(14): 1785-90.
20. Jose B Lopez Sastre, David Perez Soliz. Evaluation of procalcitonin for diagnosis neonatal sepsis of vertical transmision. BMC Pediatric 2007.

21. Suryanto CA. Uji diagnosis procalcitonin dibandingkan biakan darah sebagai baku emas untuk diagnosis sepsis bakterial di RSUP Dr. Kariadi. Semarang, FK Undip, 2012; 48-62.

22. Kelly GN. Performance of an automated immature granulosite count as predictor of neonatal sepsis. Am J ClinPathol, 2005; 123(4): 618-24.

23. Darni Fayanti, Guslihan, Dasa Tjipta, Rusdidjas, Bugis Mardiana Lubis. Immature to total neutrophil ratio as an early diagnostic tool of bacterial neonatal sepsis. Pediatr Indones, 2015; 55(33): 153-7.

24. Hornick CP, Benjamin BK, Becker KC, Benjamin DK Jr, LI $\mathrm{J}$, Clarck RH. Use of the complete blood cell count in early onset neonatal sepsis. Pediatr Infect Dis J, 2012; 31 (8): 799-802.

25. Tena R Iskandar. Validitas scoring hematologi Rodwell untuk deteksi dini sepsis neonatus awitan Dini. Sari Pediatri, 2015; 16(5): 330-6.

26. Pola Bakteri dan Kepekaan terhadap Antibiotika di RSUP Sanglah, Periode Januari-Juni 2015, SMF Mikrobiologi Klinik FK Unud, RSUP Sanglah Denpasar, 2015; 5(4): 1416. 